\title{
Autoscopy in the process of training reflective professors
}

\author{
Autoscopia no processo de formação de docentes reflexivos
}

Daniela Maysa de Souza ${ }^{1}$, Vânia Marli Schubert Backes ${ }^{1}$, Marta Lenise do Prado ${ }^{1}$, José Luis Medina Moya ${ }^{2}$

Objective: to understand how autoscopy, supported by the Model of Action and Pedagogical Reasoning, contributes to the formation of reflective professors. Methods: a qualitative and descriptive study, carried out with a Nursing professor, of the Nursing Technical Course. For the collected data, through interviews, nonparticipant observation and autoscopy, content analysis was used, with the results interpreted in the light of the referential theorist of Shulman. Results: the perceptions reported by the professor before autoscopy differ from the post-autoscopy findings, demonstrating advances in the new comprehension. The structure of autoscopy, following Shulman's Model of Action and Pedagogical Reasoning, made possible reflective professor exercise. Conclusion: the inclusion of autoscopy in teacher training processes can stimulate reflective posture, allowing for advances in teaching practices.

Descriptors: Faculty, Nursing; Nursing Faculty Practice; Education, Nursing, Associate; Nursing Education Research; Self-Assessment.

Objetivo: compreender como a autoscopia, apoiada no Modelo de Ação e Raciocínio Pedagógico, contribui para formação de docentes reflexivos. Métodos: estudo qualitativo e descritivo, realizado com uma docente de Enfermagem, do Curso Técnico em Enfermagem. Para os dados coletados, por meio de entrevistas, observação não participante e autoscopia, foi utilizada análise de conteúdo, com os resultados interpretados à luz do referencial teórico de Shulman. Resultados: as percepções relatadas pela docente antes da autoscopia diferem das conclusões pós-autoscopia, demonstrando avanços na nova compreensão. A estrutura da autoscopia, seguindo o Modelo de Ação e Raciocínio Pedagógico de Shulman, possibilitou o exercício reflexivo docente. Conclusão: a inclusão da autoscopia nos processos de formação docente pode estimular postura reflexiva, permitindo avanços nas práticas de ensino.

Descritores: Docentes de Enfermagem; Prática do Docente de Enfermagem; Educação Técnica em Enfermagem; Pesquisa em Educação de Enfermagem; Autoavaliação.

\footnotetext{
${ }^{1}$ Universidade Federal de Santa Catarina. Florianópolis, SC, Brazil.

${ }^{2}$ Universidad de Barcelona. Barcelona, Catalunha, Espanha. 


\section{Introduction}

The pedagogical training of professors in the health area has been a subject of growing concern, considering the requirements for training professionals in the area, technically, politically and ethically qualified. There is a need to overcome this gap, since traditionally in the field of health, training is directed to the exercise of professions and, rarely, to teaching ${ }^{(1-2)}$. And, to strengthen pedagogical practice, professor education is seen as a possibility, and should be offered continuously by educational institutions, with strategies, among others, that allow self-evaluation and reflection on the teaching practice itself $f^{(3)}$.

In this sense, there has been an increasing increase in research and reflection on professor training in nursing and other health areas, in the most varied aspects $^{(2,4-5)}$. One of them considers that professors can learn through reflections structured criticisms of one's own practices and a model of professor training, whose reflection is the key to professor development, allows for advances in other professors' practices in analyzing and exploring the results of these observations $^{(6)}$.

In educational research, to encourage self-reflection, autoscopy is a tool used, consisting of the use of a teaching practice that is later projected to the professor under study and aims at self-assessment $t^{(7)}$. Observing the practice in an honest and critical way ${ }^{(8)}$ allows the professor to reflect, leading him to identify the logic and motives of his actions, providing intense reflexive activity ${ }^{(9)}$.

This new understanding constitutes one of the stages of the Model of Action and Pedagogical Reasoning ${ }^{(10)}$, which occurs in six stages: comprehension, transformation, teaching, evaluation, reflection and new comprehension. Initially, the identification of one's own performance occurs, and the professor understands the presentation, evidencing the transformation of knowledge about the content to be taught, applied to the practice, in the teaching stage, and this process of evaluation of the pedagogical route allows reflecting on potentialities and weaknesses, leading to a new understanding of their performance, enabling improvements in teaching, resulting from the experience proposed by the Action Model and Pedagogical Reasoning $^{(10)}$.

Autoscopy was used in different contexts ${ }^{(7-9,11)}$, with the result that professors can justify actions and expose their reflections on how they understand the teaching process, making it possible to understand aspects of practice that require improvement and which will strengthen future professor performance ${ }^{(11)}$.

At the moment of autoscopy, the reflexive dialogue, mediated by the mentor, allows the self-analysis and revision of the teaching practice, allowing reflection on the logic that sustains the practice and respective didactic consequences ${ }^{(9)}$. The professor sees in action the Model of Action and Pedagogical Reasoning and manages to broaden the understanding of the praxis, searching strategies of professor strengthening. And as they become more aware of their practices, when they discuss their work, professors learn from their own experiences ${ }^{(6)}$.

Thus, the use of autoscopy, as a tool to be included in professor training processes, is seen as a tool to stimulate the reflective teaching process, anchored in the actions of mentoring. The study is therefore justified due to the need to reflect on aspects of teaching practice that require improvement.

And, from the research question: How can Shulman's Model of Action and Pedagogical Reasoning be applied to structure an autoscopy section? , this study aimed to understand how autoscopy, based on Shulman's Model of Action and Pedagogical Reasoning, contributes to the formation of a reflective professor.

\section{Methods}

It is a qualitative and descriptive study, supported by the Model of Action and Pedagogical Reasoning ${ }^{(10)}$. Twenty-nine final students of the Nursing Technical Course, from the only School in the municipality that offered the Course, in the Southern Region 
of Brazil, indicated, anonymously, the best nurse professors who have had in the Course. The instrument provided contained the guidance: "During your career in the Nursing Technical Course, you had several nurse professors. We would like you to quote the professor you consider to be the best". At the time of the appointment, the only criterion for students was that the professor should be a nurse. And, after the ranking, the inclusion criteria of the study were applied: being a nurse and teaching in the course, at the time of data collection; and that of exclusion, the performance in the School for less than a year.

The choice of the final students is justified by the fact that they have had classes with several professors, allowing evaluation based on personal concepts, which they consider to be a good professor. And, it is defended the choice of good professors, so that the observation of the practices is studied, providing subsidies for the strengthening of professor training strategies, thus responding to the objective proposed in this study.

Based on the indications, the ranking and the most voted professor, with 23 nominations, did not agree to participate (did not reveal the reason) and Vanessa (fictitious name), following with eleven nominations, accepted to participate. The students were not object (only the indicated professor) and participated only in the moment of nomination of the best professors. The data collection period was from September 2015 to August 2016.

For data collection, an initial biographical interview, non-participant observation, a new pre-autoscopy and autoscopy interviews were performed. For the biographical interview, the patient was contacted by telephone (provided by the coordinator) with the professor, and the semi-structured interview in the school of action, which followed a script developed by the researcher, containing questions related to the training, motivation for choosing the profession, professional trajectory, discipline taught and teaching planning. The interview lasted 33 minutes, was recorded with a voice recorder and transcribed by the researcher, validated by the participant and, at the end a non-participant observation schedule was set according to the teaching timetable presented by the professor.

Subsequently, a non-participant observation of the teaching practice was performed during the Nursing course in a Surgical Unit, which was videotaped by the researcher, with a portable video camera, directed only at the professor. The students were previously instructed and signed the Term of Free and Informed Consent, authorizing the recording of the images. A field diary and a script of objective and subjective records were used, containing elements of the theoretical reference used, totaling 16 hours of observation (six sessions of $2 \mathrm{~h} 40 \mathrm{~min}$ ).

In addition to the observations (made during a semester, until the conclusion of the course), a new interview with Vanessa was scheduled and carried out by the same researcher in the school of work. This pre-autoscopy interview lasted 20 minutes, was videotaped, transcribed by the researcher and validated by the participant. This interview was structured from the Pedagogical Action Model and Reasoning ${ }^{(10)}$ (Figure 1) and the objective was to reflect on the conduction of the discipline and the performance of the professor.

Subsequently, an autoscopy was performed, which was videotaped, with a duration of 50 ', in which the selected videotaped clippings of the sessions were presented, which represented moments related to the posture and conduction of the teaching process, which attracted attention, through the teaching conduct and/or student.

The professor was oriented so that each projected cut reflected and discoursed from the trigger: observations and reflections of this related to the own acting in the selected pedagogical moment. In this way, each clipping was projected and the video was paused, so that the professor could comment on the perceptions about the projected pedagogical moment.

The reflection was mediated by the researcher, using an instrument that contained the recording of the moments selected for projection, containing infor- 
mation related to the categories of analysis.

The material was submitted to content analy$\operatorname{sis}^{(12)}$, which followed the phases of pre-analysis, material exploration, treatment of results, inference and interpretation, allowing the subsequent creation of categories and subcategories. From the interview that preceded the autoscopy, the category: Action Model and Pedagogical Reasoning - Teaching Self-Assessment emerged. And, due to autoscopy, the category: Autoscopy and Teaching Reflection - New Under- standing appeared, with two subcategories: Teaching Posture and Reflective Dialogue.

The study was approved by the Research Ethics Committee of the Federal University of Santa Catarina, Brazil, with Certificate of Presentation for Ethical Appraisal no 48333815.3.0000.0121 and opinion $\mathrm{n}$ 1.226.620, respecting the ethical principles required, as well as the anonymity of the participant, who signed the Term of Free and Informed Consent.

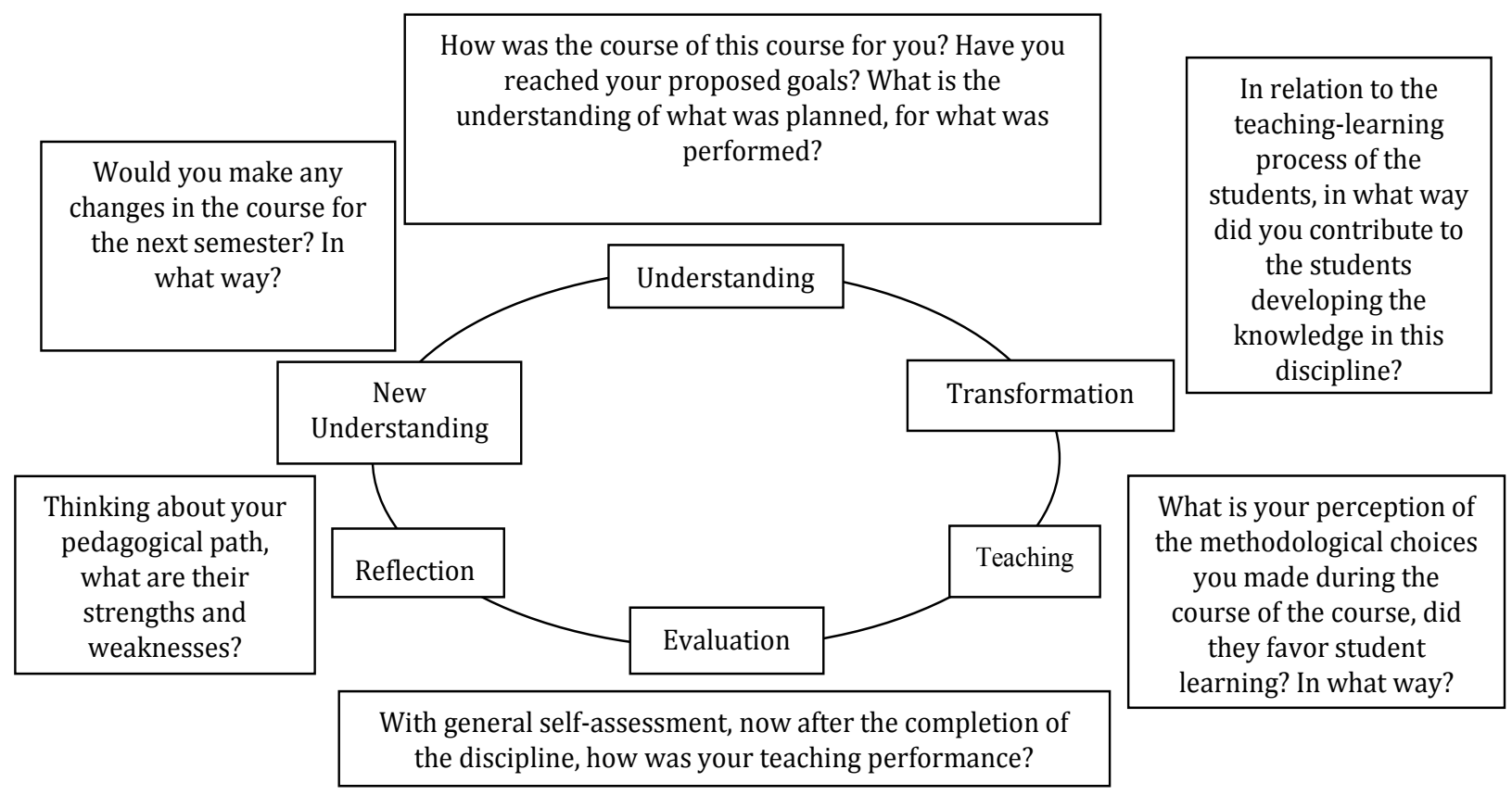

Figure 1 - Structured reflection from the Model of Action and Pedagogical Reasoning ${ }^{(10)}$

\section{Results}

Vanessa, 31, Bachelor of Nursing, with five years of teaching experience, reported that she started as a Nursing Technician and later attended a graduation and specialization in Surgical Center, with a hospital operation. He studied subjects related to didactics and started teaching at the higher level. She taught "Nursing in a Surgical Unit" (observed sessions) and, for planning, she followed a course plan and prepared a single lesson plan, adapting the constructed materials. She alternated practices in the nursing laboratory with lectures.
Action Model and Pedagogical Reasoning Self-assessment Professor: his/her understanding of the proposed planning and the achievement of the objectives was favorable and stated that the fact of having taught the theory and supervising the internship confirmed the good development of the activities ...The objectives were all contemplated (Vanessa). In order to help the moment of the transformation of the content and to enable the learning, the professor used an application to exchange messages, in which, in the practical classes (after theorizing and practice), the techniques 
performed by students were filmed. Each group has a technique and then I join everyone and we simulate a surgery... (Vanessa). And some demands are individually pointed out, stimulating student self-assessment. At the time of her teaching, Vanessa used fixing exercises to stimulate her memorization. When Vanessa thought about the assessment at the time of the end of the subject, she liked the final result, perceiving herself rigid. ...Sometimes, being a slightly more rigid professor, to charge ...in the end, I see that they leave my unit knowing what is at least the basics of the surgical center... (Vanessa). At the moment of the reflection, identified as potentiality the persuasion, when the student identified with the discipline, even if initially did not feel motivated. And, as a weakness, he pointed out that he should know more about the individual need of the students, because he could not attend to all the needs individually. About impairing comprehension, when asked if something would change in the conduct of the discipline, related to the accomplishment of more practical classes, the number of slides he used.

Autoscopy and Teaching Reflection - New Understanding: The Teaching Posture subcategory represented the findings related to the posture and personality of the professor, more authoritarian and incisive, when focusing learning on student error. To exemplify, the projected cut showed the moment the professor used the venepuncture tray assembled by the students in the previous class. He presented how the material was inadequate and reprimanded them, saying that they could not distinguish the techniques while explaining and handling the material. I can see well the part that I tease them. So that they see ...that will not happen... all the doubts that they had will appear (Vanessa). Oriented to reflect on the form of communication, how she used the error and that she theorized alone (the difference in materials), the professor reported: Fluid therapy is there in the first module ... There is no point in wanting to have surgery... You see you're not going (Vanessa). In a new attempt to stimulate reflection, in order to see herself in action, taking into account the way she performed the questions and how she gave the answer, evidencing an authoritarian attitude, the professor smiled and agreed: Yes, I arrive in the field of training, you should see, everybody getting ready (Vanessa). In another clipping, the students performed different techniques and two students were sitting talking, the professor went and asked: Do you already know everything? They quickly got up and got into the practices. In another group, he asked: How difficult is it for you to read a label? (The student had taken the wrong serum and looked uncomfortable for the reprimand). The professor was again stimulated to reflect on your communication. The two who were sitting ...never participate at all ... So it is ideal at that time, the student to know that I am seeing ...there of the serum label ...read a serum label, this is not nursing, this is a tug-of-ear, so they understand it's Portuguese ... And why does error happen? So, that's the way I say it (Vanessa). When asked if the way she talked to students favored learning, or if she might have asked differently, she said: I believe we can ask, of course, many ways, but I'll tell you, today they are in the pharmacy of the surgical center, they read all the labels ... there is a moment that we have to be a bit more rigid and speak, it's just reading, it's just a thing of interpretation (Vanessa). As for the reminder of the test being mentioned at all times, when passing through the groups and saying: I can ask all the techniques, the professor reported: You put a practice, where everyone has to participate; it seems they forget the moment that will be the end and that will be decisive for them. So, I ...try to induce them to go after the target (Vanessa). When stimulated to reflect on the posture itself, the professor was asked if she used fear and threat at times, apparently students were afraid to err and express themselves, inhibited by the manner of reprimand. She reflected: He understands that he has to give more ...several times, it seems that the student forgets, that this will be charged ...I always remember ...not in the threat of the test, because it is not, it is not so that I usually put things ... and the goal of my unit will always be the conclusion of the practical test. It's not just it, but it's my main goal (Vanessa).

In the subcategory Reflective Dialogue, clippings related to the space made available by the professor were designed for the student to dialogue, reflect and clarify doubts. In the images, there was a strong mastery of content, with a more traditional teaching posture, with predominance of expository classes focused on the transmission of technical knowledge. 
It was also identified the difficulty of stimulating the dialogue with and among the students. To give an example, the clipping showed the moment when she projected a video (on anesthesia) and directed the students to walk. At the end, she did not allow space for comments and directed her to re-draft and, this time, would pause to theorize. One student began to formulate a question, Vanessa interrupted (did not wait for the question to be completed) and promptly provided the answers, without stimulating the critical and creative thinking of the student. When stimulated to reflect this moment, Vanessa does not perceive the absence of stimulus to the student reflection, nor the difficulty of the student to finish the question. When designing again, with the indication of reflecting on the space given to the student to reflect and have their own insight, the professor reflected: Sometimes, I do not give him so much opportunity to think ...maybe, during the lessons, I could give a stop ...listen to the difficulty he has there (Vanessa).

The autoscopy ended with the contextualization that the interpretations of projected cuts may be different, when explained from the point of view of the participant, allowing clarification. I grew up watching myself ...changed a little your and my conceptions ...the proof was not a threat ... when I explain what I said and because I said, you can see that it is not with this (Vanessa). And, with the consideration of how meaningful learning was provided, from the reflection of seeing itself in action, that allowed a new understanding of the teaching performance, demonstrating that the understanding of Vanessa's new understanding of the changes in conducting the course, reported before autoscopy, differed from the post-autoscopy findings, evidencing advances in the new understanding.

\section{Discussion}

This study had limitations related to the possibility of bias, considering that the participating professor might feel intimidated and/or evaluated during the study. As advances in scientific knowledge, the operational proposal used to conduct autoscopy is a highlight, as a tool to be included in professor training processes.

The difficulty of stimulating the reflexive dialogue, evidenced in this study, showed purely the incipience for the stimulus to the student reflection and the unconsciousness of how this practice favors the learning, falls from the observed practice of another novice professor ${ }^{(10)}$, who had a highly interactive, and for lack of mastery of the content, changed to a monologue, so as not to awaken in the students possibilities of alternative points of view, since he was not sure of the answers.

The stimulus to reflection allows the formation of critical, creative and reflexive students, capable of reasoning against the adversities found in the formation process. Providing moments of reflection requires the sensitivity of the professor to provide meaningful learning, which develops the autonomy of the student.

In order to promote the reflexive dialogue, professors should welcome the student's speeches with a sensitive listening. However, this difficulty of stimulating reflection is not the exclusive behavior of the beginner, since, observing ${ }^{(13)}$ the practice of intermediate professors (with six to fourteen years of experience), it was also identified a practice of traditional teaching, based on technical rationality, restricting to the know-how. In the observed practice of an experienced professor, with 25 years of performance, it was demonstrated that the teaching style stands out highly interactive and interrogative, stimulating debates and alternative views of the same subject with a combination of content mastery and pedagogical ability ${ }^{(10)}$, suggesting that these skills are developed over time and improved over time.

There is a possibility of stimulating student reflection through mediation of learning about error. However, posture is necessary that does not repress the student and, rather, motivates him to find solutions to his own mistakes. The student should be encouraged to reflect on his/her own conduct and, it is up to the professor, to stimulate him to think and question his own actions, so that, in a reflexive way, he 
builds his own learning ${ }^{(14)}$.

The error is related to the unexpected, to the unforeseen and the important thing is to learn from the experience of this discovery and the resolution of problems, however, not all experiences can be educational ${ }^{(8)}$; when a more authoritarian stance can reprimand the student, for fear of reprehension and exposure of error. Talking and listening to the student, seeking to understand the context requires reciprocally reflective dialogue, so that it can perceive the potentialities and weaknesses of the formation ${ }^{(15)}$.

Another possibility of reflexive teaching is through the use of videos, whose subject is simulated using debriefing ${ }^{(16)}$, allows the student to examine the practice through observation, along with feedback received from the professor, promoting the consolidation of knowledge, seen by students as a source of learning ${ }^{(17)}$.

Enabling such learning demonstrates the integration of knowledge: technological, content and pedagogical, and this is the basis of the Technological Pedagogical Content Knowledge, a theory derived from Shulman constructs, which enables effective learning experiences. And considering the use of technologies, the challenge is to ensure that professors are prepared to introduce them, resignifying pedagogic strategies useful to learning ${ }^{(18)}$.

Simulations and virtual experiences in reflexive practical teaching enable the students to think critically about practices, expanding their thinking skills, relying on the professor, stimulating reflection and mediating this process ${ }^{(19)}$. Thus, to offer reflective teaching, first the professor needs to be reflective and in studying his own practice, can revitalize it.

The stimulus to reflection and study of the practice itself can be experienced in the autoscopy session, demonstrating itself as a strategy useful for this purpose, since the practice of mentoring allows the direction of actions. When visualizing and clarifying the actions in the classroom, autoscopy requires that professors reflect and explain the planning of future actions, providing elements that, when interacting with each other, constitute a base that strengthens the teaching repertoire, aiming to improve teaching practice and knowledge $\mathrm{e}^{(7)}$.

An attribute for competent teaching is the ability to self-criticism, reflect and learn from experience, and the use of videos from the lessons themselves enables the professor to learn to improve teaching through active reflection provided ${ }^{(6)}$. Thus, in order to offer reflexive teaching, the professor must first be reflective, to construct and reconstruct knowledge from what he does and starting from this epistemological curiosity, modify the teaching style, moving towards more liberating practices ${ }^{(14)}$.

From these individual experiences and the new understanding that autoscopy allows, these data can be analyzed in terms of pedagogical and learning processes, and more general elements can be extracted, connecting them with part of a professor training curriculum, allowing personal and professional development ${ }^{(6)}$. And, when considering competencies required in the face of teaching complexity, professor training programs should stimulate changes in thinking and teaching, collectively impacting, stimulating reflection and developing new skills, from the perspective of a permanent culture of professor training ${ }^{(20)}$.

In this way, it is necessary to reciprocate reflection, of professors and students, strengthening the pedagogical relationship of both. It is up to the professor to find alternatives and raise awareness for the realization of the reflexive process, with pedagogical training itself being one of these opportunities for acquiring new skills ${ }^{(15)}$.

\section{Conclusion}

The operational proposal of the autoscopy allowed the movement of the Model of Action and Pedagogical Reasoning, generating a new understanding of the teaching practice. The inclusion of autoscopy in the processes of professor training, mediated by a mentor, can stimulate reflective posture, allowing for advances in teaching practices. 


\section{Acknowledgments}

To the Coordenação de Aperfeiçoamento de Pessoal de Nível Superior (Coordination of Improvement of Graduates), process no 88881.134121/201601, and to the Program of University Scholarships of Santa Catarina, Brazil.

\section{Collaborations}

Souza DM participated in the project design, analysis and interpretation of the data. Backes VMS contributed with data analysis and interpretation. Prado ML and Moya JLM collaborated with relevant critical review of the intellectual content and approval of the final version to be published.

\section{References}

1. Backes VMS, Menegaz JC, Carvalho MFA, Santos LMC, Cunha AP, Souza PS. Lee Shulman: contributions to research on teacher training in nursing and health. Texto Contexto Enferm. 2017; 26(4):e1080017. doi: dx.doi.org/10.1590/010407072017001080017

2. Treviso P, Costa BEP. The perception of professionals from the health area regarding their training as lecturers. Texto Contexto Enferm. 2017; 26(1):e5020015. doi: dx.doi.org/10.1590/010407072017005020015

3. Souza DM, Backes VMS, Prado ML. Formação docente na educação profissional técnica de nível médio: uma revisão integrativa da literatura. Interfaces Educ. 2016; 7(20):211-35. doi: https:// doi.org/10.26514/inter.v7i20.987

4. Menegaz JC, Backes VMS, Moya JLM. Pedagogical reasoning and action of professors of nursing: expressionsin differenteducational contexts. Texto Contexto Enferm. 2018; 27(3):e2660016. doi: dx.doi.org/10.1590/0104-07072018002660016

5. Peres CRFB, Marin MJS, Tonhom SFR, Marques MLSF. Current challenges in nursing education: the professor's perspective. Rev Rene. 2018; 19:e3160. doi: http://dx.doi.org/10.15253/21756783.2018193160
6. Shulman LS, Shulman JH. Como e o que os professores aprendem: uma perspectiva em transformação. Cad Cenpec. 2016; 6(1):120-42. doi: dx.doi. org/10.18676/cadernoscenpec.v6i1.353

7. Piratelo MVM, Teixeira LA, Arruda SM, Passos MM. As Relações Epistêmicas com os saberes docentes em sala de aula em um PIBID/Física. Rev Educ Ciênc Mat [Internet]. 2017 [citado 2019 mar 17]; 7(1):165-81. Disponível em: http://publicacoes. unigranrio.edu.br/index.php/recm/article/ view/3968/0

8. Shulman LS. Educational innovation with open eyes and no excuses: the challenges and opportunities of learning from experience. REGIES [Internet]. 2016 [cited May 20, 2019];1:13-28. Available from: http://ojs.inacap.cl/index.php/regies/article/view/16/38

9. Soto MC, Marín R, Guzmán I. Análisis reflexivo de la práctica educativa del educador físico. Omnia [Internet]. 2017 [cited Mar 29, 2019];23(2):4655. Available from: https://www.redalyc.org/ articulo.oa?id=73754834005

10. Shulman LS. Conhecimento e ensino: fundamentos para a nova reforma. Cad Cenpec. 2014; 4(2):196229. doi: dx.doi.org/10.18676/cadernoscenpec. v4i2.293

11. Carvalho DF, Passos MM. A autoscopia e o desenvolvimento da autonomia docente. Rev Educ Ciênc Mat. 2014; 20(10):80-100. doi: http://dx.doi. org/10.18542/amazrecm.v10i20.2300

12. Minayo MCS. O desafio do conhecimento: pesquisa qualitativa em saúde. São Paulo: Hucitec; 2014.

13. Canever BP, Prado ML, Gomes DC, Jesus BH, Backes VMS. Naive World Awareness in the Pedagogical Practice of Healthcare Professors. Texto Contexto Enferm. 2017; 26(2):e3340015. doi: http:// dx.doi.org/10.1590/0104-07072017003340015

14. Winters, JRF, Prado ML, Waterkemper R, Kempfer SS. Dialogical and participative training in nursing education: contribution to the development of critical and reflective and creative thinking of students. Rev Min Enferm. 2017; 21:e1067. doi: www.dx.doi.org/10.5935/1415-2762.20170077 
15. Lima MM, Reibnitz KS, Kloh D, Vendruscolo C, Corrêa AB. Dialogue: network that intertwines the pedagogical relationship into the practical-reflective teaching. Rev Bras Enferm. 2016; 69(4):610-7. doi: http://dx.doi.org/10.1590/ 0034-7167.2016690406i

16. Coutinho RDC, Martins JCA, Pereira MFCR. Construção e validação da Escala de Avaliação do Debriefing associado à Simulação (EADaS). Rev Enf Ref. 2014; 4(2):41-50. doi: http://dx.doi. org/10.12707/RIII1392

17. Elarousy W, Beer J, Alnajjar H. Exploring the experiences of nursing students during debriefing: a qualitative study. Am J Nurs [Internet]. 2019 [cited May 23, 2019];7(3):310-5. Available from: http://www.sciepub.com/AJNR/content/7/3
18. Nakashima RHR, Piconez SCB. Technological Pedagogical Content Knowledge (TPACK): modelo explicativo da ação docente. Rev Educ. 2016; 10(3):231-50. doi: http://dx.doi. org/10.14244/198271991605

19. Ribeiro OMPL, Martins MMFP, Carvalho ALRF, Santos LMMM, Viana MFR. Views on nursing education in Portugal. Rev Rene. 2018; 19:e3313. doi: dx.doi.org/10.15253/2175-6783.2018193313

20. Menegaz JC, Backes VMS, Medina JL, Prado ML, Canever BP. Pedagogical practices of good nursing, medicine and dentistry professors from the students' perception. Texto Contexto Enferm. 2015; 24(3):629-36. doi: http://dx.doi. org/10.1590/0104-07072015002790014 